\title{
Molecular Diversity of Local Spanish Sweet Cherry Cultivars by SSR and $S$-Locus Analysis
}

\author{
A.M Cachi ${ }^{1}$, M. López-Corrales ${ }^{2}$, A. Arbeloa ${ }^{3}$, R. Gella ${ }^{1}$ and A.Wünsch ${ }^{1}$ \\ ${ }^{1}$ Unidad de Fruticultura, Centro de Investigación y Tecnología Agroalimentaria de Aragón \\ Ctra. Montañana 930, 50059 Zaragoza, Spain. \\ ${ }^{2}$ Departamento de Hortofruticultura, Centro de Investigación Finca La Orden Valdesequera. \\ Apdo. 22, 06187 Badajoz. \\ ${ }^{3}$ Departamento de Pomología, Estación Experimental Aula Dei, CSIC. Avda. Montañana \\ 1005, 50059 Zaragoza.
}

Keywords: sweet cherry, genetic diversity, local germoplasm, microsatellite, S-alleles

\begin{abstract}
Sweet cherry cultivar renewal in fruit orchards is leading to the reduction of local genetic diversity and traditional cultivars are fallen into disuse. In order to conserve this genetic diversity it is necessary to collect maintain and characterize this autochthonous germplasm. Previous genetic and morphological analyses of local varieties from eastern Spain have revealed the existence of a genetic pool that is well differentiated from the rest of cultivated material. In this work local cherry varieties collected from northern Spain, the Mediterranean coast, the Balearic Islands as well as from the Spanish eastern regions have been analysed and compared by PCR and capillary electrophoresis detection using microsatellite markers and the $S$-locus. The work has allowed to determine genotype identities as well as to study the existing genetic diversity. Microsatellite analysis grouped the cultivars in various distinct clusters that mostly correlate with their geographical origin. $S$-allele diversity revealed higher frequency of certain $S$-alleles as well as the unique presence of some $S$-alleles in most isolated geographical areas. The results obtained will be useful for the management and conservation of this local germplasm.
\end{abstract}

\section{INTRODUCTION}

Sweet cherry (Prunus avuim L.) is reported to have originated in an area between the Black Sea and the Caspian Sea (Webster, 1996) and was an early derivative of an ancestral Prunus native to central Asia (Iezzoni, 2008). As sweet cherry spread throughout Europe, centuries of domestication and cultivation in different areas have resulted in the development of specific ecotypes (Iezzoni et al, 1990). Each ecotype developed certain features like cold hardiness, tree habit and fruit and leaf characteristic that allow its adaptation to each area (Iezzoni, 2008).

In Spain, sweet cherry is one of the most economically important stone fruits with a production of $76.000 \mathrm{t}$ in 2007 (FAOSTAT, 2007). More than the $50 \%$ of the production comes from Extremadura and Aragon with 23.000 and 20.000 t respectively (MAPA, 2008). Studies analysing the diversity of local Spanish cherry varieties have shown the existence of 
local genotypes that are morphologically and genetically different from the rest of cultivated cherries (Pérez- Sánchez et al. 2008; Wünsch and Hormaza. 2004a). Today, more uniform and productive cultivars are replacing traditional ones in fruit orchards which leads to the disuse of the local cultivars and to the reduction of the cultivated genetic diversity. Molecular characterization and genotype identification and the possibility of studying the genetic diversity among these cultivars and populations are necessary for their correct conservation and management.

Microsatellites markers or SSRs (Lit and Lutty, 1989) have become a useful tool for sweet cherry genotyping, germoplasm characterization, fingerprinting as well as for the determination of genetic relatedness. The selection of these markers is based on their high level of polymorphism, codominant inheritance, abundance in the genome and their high reproducibility (Wünsch and Hormaza 2002a). Difficulties associated with the initial isolation of SSRs were overcome with their transportability between related species (Dirlewanger et al, 2002; Hormaza, 2002; Wünsch and Hormaza 2002b) and several studies have used these markers for the identification and estimation of the genetic diversity in sweet cherry cultivars (Dirlewanger et al. 2002, Wunsch and Hormaza 2002b, 2004a).

Sweet cherry is a naturally self-incompatible species and self-incompatibility is genetically determined by a multiallelic locus, named S-locus (Crane and Lawrence, 1929). The specificity of this pollen-pistil interaction is determinate by two closely linked genes, $S$ RNase and SFB, located at the $S$ locus (Bošković and Tobutt, 1996; Yamane et al., 2003). The characterization of the genomic DNA sequences of the sweet cherry S-RNase allowed the identification of $S$-alleles by PCR analysis. The $S$-RNase has three exons and two introns that vary in size for each $S$-allele (Tao et al., 1999). Primers designed in the conserved regions of sweet cherry $S$-RNases amplify fragments of different size for each $S$-allele and different strategies have been developed to detect this polymorphism (Tao et al., 1999; Wiersma et al., 2001: Sonneveld et al., 2003; 2006). More recently other PCR strategies have also been designed to detect the $S$-allele polymorphism found in SFBs and associated to the intron present (Vaughan et al., 2006). In sweet cherry, $31 \mathrm{~S}$-alleles have been detected using these techniques (Tao et al., 1999; Sonneveld et al., 2001; Wiersma et al., 2001; Sonneveld et al., 2003; Wünsch y Hormaza, 2004b; De Cuyper et al.; 2005; Vaughan et al., 2008). The knowledge of the $S$-haplotype of each cultivar and their assignment to their corresponding Incompatibility Group allow the determination of cultivar compatibilities and therefore the optimization orchard management, but $S$-locus is also a useful marker to study the genetic diversity of different cultivars.

In this work 48 sweet cherry local accessions from different growing areas were analysed using microsatellites and for the $S$ - locus, and this information was used to determine genotype identities as well as to study the existing genetic diversity.

\section{MATERIALS AND METHODS}

\section{Plant material and DNA extraction}

Forty eight local Spanish sweet cherry accessions from different regions were used in this study. The plant material included genotypes from Cantabria, Aragon, Catalonia, Castellon, Extremadura and the Balearic Islands. One Italian and 6 French cultivars were also 
included for comparison because they have been traditionally cultivated in Spain. DNA was extracted from young leaves of each accession following the protocol described by Hormaza (2002).

\section{SSRs Analysis}

Prunus SSRs markers were used to characterize the 48 local sweet cherry accessions. Two American varieties 'Vic' and 'Compact Stella' were included in this analysis as outgroup to compare with the local varieties. Genomic DNA from each accession was used to amplify 14 SSRs loci (Table 1) detected by capillary electrophoresis using a Genetic Analyser and fluorescent labelled primers (Fig. 1). SSR amplification was carried out in $20 \mu \mathrm{l}$ volumes containing $20 \mathrm{mM}$ Tris- $\mathrm{HCl}, \mathrm{pH} 8.4,50 \mathrm{mM} \mathrm{KCl}, 4 \mathrm{mM} \mathrm{MgCl}_{2}, 0.1 \mathrm{mM}$ each dNTP, $0.2 \mu \mathrm{M}$ each primer, $40 \mathrm{ng}$ genomic DNA and 0.45 units of Taq DNA Polymerase (Invitrogen). PCR reactions were carried out using the following temperature profile: an initial step of 2 minutes at $94^{\circ} \mathrm{C}, 35$ cycles of 45 seconds at $94^{\circ} \mathrm{C}, 45$ seconds at $57^{\circ} \mathrm{C}$ and 1 minute at $72^{\circ} \mathrm{C}$, and a final step of 5 minutes at $72^{\circ} \mathrm{C}$. For capillary electrophoresis the genetic analyser ABI PRISM 310 (Applied Biosystems) was used and size calling of the fragments was carried out using the standard 500 GeneScan LIZ (Applied Biosystem) and the GeneScan 3.1 software package (Applied Biosystem). Forward primers for capillary electrophoresis were labelled with different fluorescence dyes (6-FAM, NED, VIC and PET). Genetic similarity from the SSR data and PCA (Principal Component Analysis) grouping was estimated using GenAlEx6 software. These results allowed us to define the genetic profile of each accession and to estimate the genetic similarities among the accessions analysed.

\section{S-locus Analysis}

The $S$ genotype of the 48 local accessions was determined by PCR analysis. Twenty accessions had been previously analyzed for the $S$-RNase alleles (Wünsch y Hormaza, $2004 \mathrm{a}, \mathrm{b})$, and were analyzed in this work for both $S$ genes by capillary electrophoresis in order to confirm their $S$ genotypes. The remaining 28 accessions were analyzed for the first time in this work. DNA from each accession was used to amplify both genes of the $S$ locus (S-RNase and SFB) with two primers pairs PaConsI-F/PaConsIR2 and FBOX5'A/FBOXintronR (Sonneveld et al 2006, Vaughan et al 2006) by PCR. Amplification products were detected by capillary electrophoresis (Fig. 2). All the PCR reactions were performed in $20 \mu \mathrm{l}$ volumes containing $20 \mathrm{mM}$ Tris- $\mathrm{HCl}, \mathrm{pH} 8.4,50 \mathrm{mM} \mathrm{KCl}, 2 \mathrm{mM} \mathrm{MgCl} 2,0.1 \mathrm{mM}$ of each dNTP, $0.2 \mu \mathrm{M}$ of each primer, $40 \mathrm{ng}$ of genomic DNA and 0.45 units Taq polymerase (Invitrogen). Reactions were carried out using the following temperature profile: an initial step of $3 \mathrm{~min}$ at $94{ }^{\circ} \mathrm{C}, 35$ cycles of $1 \mathrm{~min}$ at $94{ }^{\circ} \mathrm{C}, 1 \mathrm{~min} 55^{\circ} \mathrm{C}$ and $2 \mathrm{~min}$ at $72{ }^{\circ} \mathrm{C}$, and a final step of $7 \mathrm{~min}$ at $72{ }^{\circ} \mathrm{C}$. For capillary electrophoresis the genetic analyser ABI PRISM 310 (Applied Biosystems) was used and size calling of the fragments was carried out using the standard 500 GeneScan LIZ (Applied Biosystem) and the GeneScan 3.1 software package (Applied Biosystem). Forward primers for capillary electrophoresis were labelled with different fluorescence dyes (6-FAM and NED). 


\section{RESULTS AND DISCUSSIONS}

The SSR analysis allowed comparing the different accessions profiles, to identify synonyms, to determine the identity of some old accessions and to compare and confirm homomyms conserved in different regions. Forty six different genotypes from the 48 accessions analysed were identified. Meanwhile $S$-locus analysis allowed determining the $S$ genotype of 44 of the 48 accessions under study and these were assigned to 12 different incompatibility groups. Eleven of the 30 known $S$-alleles were identified in this plant material.

The combined results from SSRs and the S-locus revealed a correlation between the SSR data groups and the $S$ alleles identified in each geographical region. The PCA of the SSR data grouped the accessions according to their geographical origin and showed that American varieties, introduced as outgroup, are distinct from the local Spanish and south European accessions analysed. This confirms again the genetic differentiation of the autochthonous accessions from the breeding plant material. Within the accessions of the Iberian Peninsula, there are two main distinct groups corresponding to the Extremadura accessions and the accessions from the Mediterranean regions. Most other accessions tested, from northern of Spain and France formed an intermediate group between the other two in the PCA analysis.

$S$-allele frequency per region revealed that some $S$-alleles are more frequent in some regions and some are unique to a determined geographical area. It was also confirmed that the Extremadura group has a higher frequency of alleles $S_{3}$ and $S_{6}$ (Wunsch and Hormaza, 2004a), while the allele $S_{22}$ is more frequent in the Mediterranean regions, as seen before in accessions from the Alicante region (Gisbert et al., 2008). It is interesting to note that accessions from Mallorca, which form a unique and distinct group, have allele $S_{16}$, and that this allele is only present in this region. This result reflects the interest of this plant material for conservation.

The results obtained will be useful for the management and conservation of this local germplasm and further accessions are being incorporated and will be characterize using these tools with the aim of knowing and preserving local genetic diversity of this species.

\section{ACKNOWLEDGMENTS}

This work was financed by research projects INIA (MICINN) RF2008-00028-C02-01 and RTA2006-000144 and Gobierno de Aragón Research Group 'Biología del desarrollo y material vegetal en frutales'. A. Cachi was financed with an INIA PhD grant. We thank E. García (CIFA de Muriedas, Cantabria), C. Gil (AgroXXI, Zaragoza), A. Martorell (Govern de les Illes Balears, Mallorca), C. M Pons (Mallorca), J. Orero (Viveros Orero, Castellón), C. Romero (IVIA, Valencia), A. Vila (Parc Agrari del Baix Llobregat, Barcelona) for plant material.

\section{Literature cited}

Bošković, R. and Tobutt K.R. 1996. Correlation of stylar ribonuclease zymograms with incompatibility alleles in sweet cherry. Euphytica 90: 245-250.

Crane, M.B. and Lawrence, J.C. 1929. Genetical and cytological aspects of incompatibility and sterility in cultivated fruits. J. Pom. Hort. Sci. 7:276-301. 
De Cuyper, D., Sonneveld, T. and Tobutt, K.R. 2005. Determining self-incompatibility genotypes in Belgian wild cherries. Molecular Ecology 14:945-955.

Dirlewanger, E., Cosson, P., Tavaud, M., Aranzana, M. J., Poizat, C., Zanetto, A.,P.Arús and F. Laigret. 2002. Development of microsatellite markers in peach [Prunus persica (L.) Batsch] and their use in genetic diversity analysis in peach and sweet cherry (Prunus avium L.). Theor. Appl. Genet. 105, 127-138.

Food and Agruculture Organization. 2009. www.faostat.fao.org

Gisbert, A.D., Badenes, M.L., Tobutt, K.R., Llacer, G. and Romero, C. 2008. Determination of the $S$-allele composition of sweet cherry (Prunus avium L.) cultivars grown in the southeast of Spain by PCR analysis. J.Hort. Sci Biotech. 83(2): 246-252.

Hormaza, J. I. 2002. Molecular characterization and similarity relationships among apricot (Prunus armeniaca L.) genotypes using simple sequence repeats. Theor. Appl. Genet. 104, 321-328.

Iezzoni, A.F. 2008. Cherries .p.687-693. In: Jules Janick \& R E. Paull (eds.), The Encyclopedia of Fruits and Nuts, Wallingford, Oxfordshire: CABI Publishing

Iezzoni, A.F, Andersen, R.L, Schmidt, H., Albertini, A.1990. Cherries (Prunus).p111-173. In: Moore JN, Ballington JR Jr. (eds.), Genetic Resources of Temperature Fruits and Nut Crops, Vol. 1, I.S.H.S., Wageningen, The Netherlands.

Litt, M. and Luty, J.A. 1989. A hypervariable microsatellite revealed by in vitro amplification of a dinucleotide repeat within the cardiac muscle actin gene. Am. J. Hum. Genet. 44: 397-401.

Ministerio de Medio Ambiente y Medio Rural y Marino. 2008. Anuario De Estadística Agroalimentaria. www.marm.es

Perez-Sanchez, R., Gómez-Sanchez, M.A. and Morales Corts, R. 2008. Agromorphological characterization of traditional Spanish sweet cherry (Prunus avium L.), sour cherry (Prunus cerasus L.) and duke cherry (Prunus $\times$ gondouinii Rehd.) cultivars. Sp. J. Agr. Res. 6(1): 42-55.

Sonneveld, T., Robbins, T.P., Bošković, R. and Tobutt K.R. 2001. Cloning of six cherry selfincompatibility alleles and development of allele-specific PCR detection. Theor. Appl. Genet. 102:1046-1055

Sonneveld, T., Tobutt, K.R. and Robbins, T.P. 2003. Alleles-specific PCR detection of sweet cherry self-incompatibility $(S)$ alleles $S_{1}$ to $S_{16}$ using consensus and alleles-specific primers. Theor. Appl. Genet. 107:1059-1070.

Sonneveld, T., Robbins, T.P. and Tobutt, K.R. 2006. Improved discrimination of selfincompatibility $S$-RNase alleles in cherry and high throughput genotyping by automated sizing intron PCR products. Plant Breedring. 125:305-307.

Tao, R., Yamane, H., Sugiura, A., Murayama, H., Sassa, H. and Mori, H. 1999. Molecular typing of $S$-alleles through identification, characterization and cDNA cloning for $S$ RNases in sweet cherry. J. Amer. Soc. Hort. Sci. 124:224-233.

Vaughan, S.P., Russell, K., Sargent, D.J. and Tobutt, K.R. 2006. Isolation of S locus F-box alleles in Prunus avium and their application in a novel method to determine selfincompatibility genotype. Theor. Appl. Genet. 112:856-866. 
Vaughan, S.P., Bošković, R., Gisbert-Climent, A., Russell, K. and Tobutt, K.R. 2008. Characterization of a novel S-alleles from cherry (Prunus avium L.) Tree Genet. Genomes 4:531-541.

Webster, A.D. 1996. p.3-24. The taxonomic classification of Sweet and Sour Cherries and a brief history of their cultivation. In: Webster, A.D. and Looney, N.E. (eds) Cherries: Crop physiology, production and uses, CAB International, Wallingford, Oxon, UK.

Wiersma, P.A., Wu, Z., Zhou, L., Hampson, C. and Kappel, F. 2001. Identification of selfincompatibility alleles in sweet cherry (Prunus avium L.) and clarification of incompatibility groups by PCR and sequencing analysis. Theor. Appl. Genet. 102:700708.

Wünsch, A. and Hormaza, J.I. 2002a. Cultivar identification and genetic fingerprinting of temperate fruit tree species using DNA markers. Euphytica 125: 59-67.

Wünsch, A. and Hormaza, J.I. 2002b. Molecular characterisation of sweet cherry (Prunus avium L.) genotypes using peach [Prunus persica (L.) Batsch] SSR sequences. Heredity 89: 56-63.

Wünsch, A. and Hormaza, J.I. 2004a. Molecular evaluation of genetic diversity and S-allele composition of local Spanish sweet cherry (Prunus avium L.) cultivars. Genet. Resour. Crop Evol. 51: 635-641.

Wünsch, A. and Hormaza, J.I. 2004b. S-Allele identification in sweet cherry cultivars by PCR analysis. Plant Breed. 127: 327-331

Yamane, H., Ikeda, K., Sassa, H. and Tao, R. 2003. A pollen expressed gene for a novel protein with an F-box motif that is very tightly linked to a gene for $S$-RNase in two species of cherry, Prunus cerasus and P. avium. Plant Cell Physiol. 44:764-769.

\section{Tables}

Table 1. List of SSRs analysed.

\begin{tabular}{ll}
\hline SRRs & References \\
\hline UDP96-005, UDP98-409 & Cipriani et al. 1999 \\
UDP98-410 & Testolin et al. 2000 \\
Pchgms1, pchcms5, ps12a02, ps08e08 & Sosinski et al. 2000 \\
CPPCT-6 & Aranzana et al. 2002 \\
BPPCT-002, BPPCT-004, BPPCT-007 & Dirlewanger et al. 2002 \\
BPPCT-10, BPPCT-014, BPPCT-026 & \\
\hline
\end{tabular}

\section{Figures}

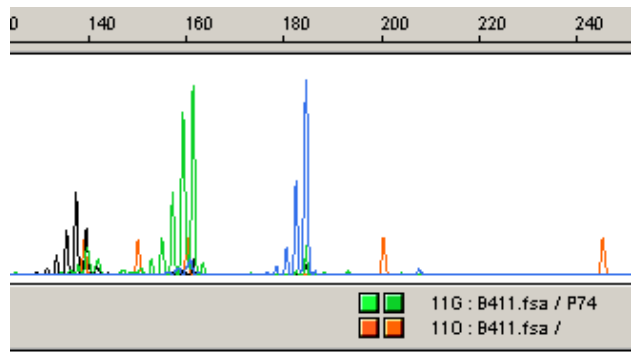


Figure 1.Microsatellite alleles amplified with SSRs 'pchgms1' (black), 'ps12a02' (green) and 'CPPCT-6' (blue) in 'Garrafal' (a), 'Temprana de Sot' (b) and 'Ramillete' (c).

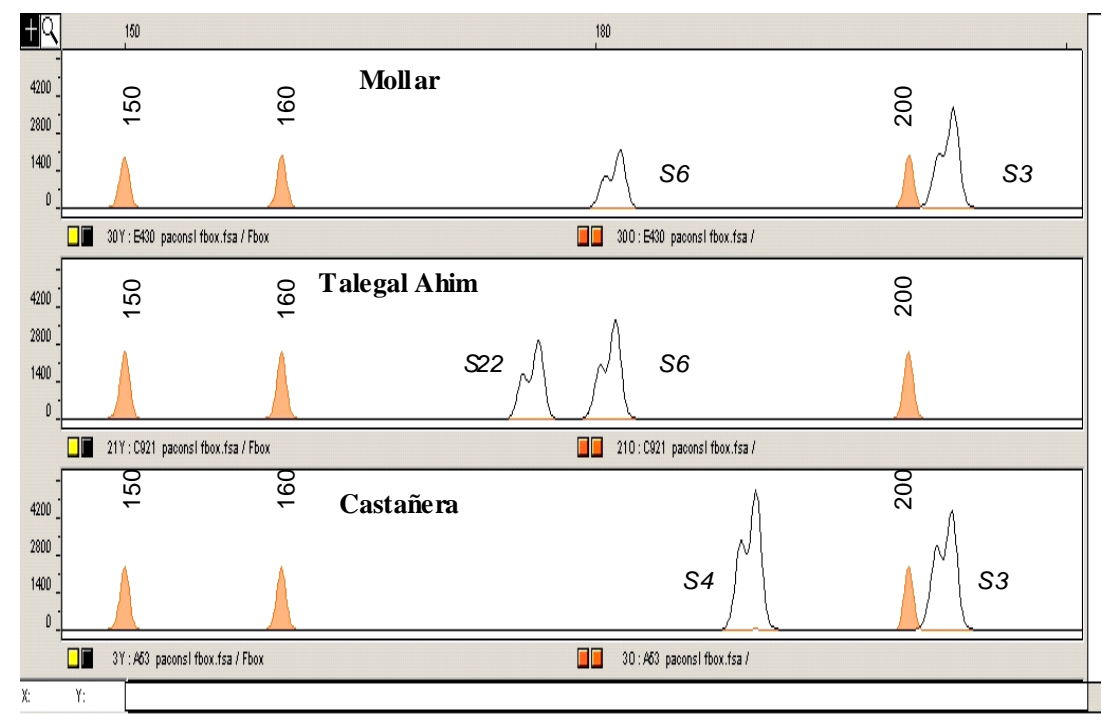

Figure 2. SFB amplification with FBOX5'A/F-BOXintronR primers (Sonneveld et al 2006, Vaughan et al 2006) in Mollar, $S_{3} S_{6}$ (a), Talegal Ahim, $S_{6} S_{22}$ (b) and Castañera, $S_{3} S_{4}$ (c). 